\title{
PENGARUH PERSEPSI KONSUMEN DAN STORE ATMOSPHERE TERHADAP KEPUTUSAN PEMBELIAN KONSUMEN PADA BASKO GRAND MALL (STUDI PADA MASYARAKAT KOTA PADANG)
}

\author{
Mega Sundari, Febsri Susanti \\ Sekolah Tinggi Ilmu Ekonomi "KBP" \\ febsrisusanti@akbpstie.ac.id \\ megasundari600@gmail.com
}

\begin{abstract}
Modern retail business continues to grow in Indonesia is a very promising market. business people must be able to apply the right strategy to make consumer purchasing decisions in the retail market. Consumer perceptions and store atmosphere one of the factors that can influence consumer purchasing decisions. This research was conducted to determine the influence of consumer perceptions and store atmosphere on consumer purchasing decisions in Basko Grand Mall Padang. The sample used accidental sampling with 96 respondents. With the technique of data collection questionnaires distribution as a research instrument and processed using spss calculation 16. Data analysis method used is multiple linear regression. The result of the research shows the relationship of consumer perception and store atmosphere to consumer purchase decision partially or simultan.
\end{abstract}

Keywords: consumer purchase decisions, consumer perceptions, modern retail, store atmosphere.

\section{PENDAHULUAN}

Kota Padang sebagai salah satu kota yang sedang mengalami perkembangan pesat memiliki potensi yang baik sebagai daerah perluasan pangsa pasar. Hingga saat ini, di kota Padang telah berdiri pusat berbelanja modern seperti Basko Grand Mall, Plaza Andalas, SPR (Sentral Pasar Raya) dan lain-lain. Hal ini mengakibatkan terjadinya persaingan yang ketat diantara pusat perbelanjaan modern tersebut. Mengantisipasi persaingan yang ketat maka pihak yang terlibat dalam pusat perbelanjaan modern harus dapat merumuskan strategi yang tepat untuk dapat bersaing di tengah persaingan yang ketat serta untuk mendorong pertumbuhan dan perkembangan usaha mereka. Salah satu yang dapat dilakukan oleh para pelaku usaha tersebut adalah memahami dan mengetahui tentang kebutuhan dan keinginan konsumen, dan faktor-faktor yang dapat mempengaruhi 
keputusan mereka untuk melakukan pembelian. Beberapa faktor yang dapat mempengaruhi keputusan pembelian seperti faktor internal dan eksternal.

Menurut Utami (2006), faktor intrernal yang dapat mempengaruhi keputusan belanja adalah aspek psikologis, salah satunya yaitu persepsi konsumen. Menurut Sumarwan (2011), pemasar (produsen) yang mengerti perilaku konsumen akan mampu memperkirakan bagaimana kecendrungan konsumen untuk bereaksi terhadap informasi yang diterimanya, sehingga pemasar (produsen) dapat menyusun strategi pemasaran yang sesuai. Dari pernyataan tersebut penelitian mengenai persepsi konsumen sangat penting karena pemasar dapat menyusun strategi yang tepat untuk mengetahui apa yang diinginkan konsumen agar dapat menarik minat beli, dan akhirnya memutuskan untuk melakukan pembelian.

Salah satu kondisi eksternal yang mempengaruhi keputusan pembelian konsumen adalah store atmosphere. Hal ini dapat terlihat dari berbagai pusat perbelanjaan modern tidak hanya dikunjungi konsumen untuk sekedar berbelanja namun sebagian konsumen juga mengunjungi tempat-tempat pusat perbelanjaan modern untuk jalan-jalan, refresing, dan menghabiskan waktu luang. Menurut Karmela dan Junaedi (2009) suasana yang menyenangkan, menarik, nyaman, dan mampu menciptakan satu atmosfer yang secara positif dapat mempengaruhi perilaku konsumen, sehingga menimbulkan minat beli, dan akhirnya memutuskan untuk melakukan pembelian. Store atmosphere sebagai salah satu sarana komunikasi dapat berakibat positif dan menguntungkan jika dibuat secara menarik. Konsumen akan merasa nyaman berbelanja, jika store atmosphere atau suasana tokonya mendukung minimal konsumen atau calon konsumen akan merasa betah berlama-lama berbelanja dan semakin memperbesar peluang konsumen untuk melakukan pembelian.

\section{LANDASAN TEORI}

\section{Persepsi Konsumen}

\section{Pengertian Persepsi Konsumen}

Menurut Kotler dan Keller (2012) persepsi adalah proses yang digunakan oleh individu untuk memilih, mengorganisasi, dan menginterpretasi masukan informasi guna menciptakan gambaran dunia yang memiliki arti. Setiadi (2010), mendefinisikan sebagai proses dimana seseorang memilih, mengorganisasikan, mengartikan masukan informasi untuk menciptakan suatu gambaran yang berarti dari dunia ini. Persepsi merupakan suatu proses yang timbul akibat adanya sensasi, yaitu tanggapan yang cepat dari indra penerima kita terhadap stimuli dasar seperti cahaya, warna, dan suara, stimuli-stimuli itu diseleksi, diorganisasikan, dan diinterpretasikan.

\section{Store Atmosphere}

\section{Pengertian Store Atmosphere}

Utami (2006), mendefinisikan suasana toko sebagai kombinasi dari karakteristik fisik toko seperti arsitektur, tata letak, pencahayaan, pemajangan, warna, temperatur, musik, serta aroma yang secara menyeluruh akan menciptakan citra dalam benak konsumen. Melalui suasana toko yang sengaja diciptakan, ritel berupaya untuk mengkomunikasikan informasi yang terkait dengan layanan, harga, maupun ketersediaan barang dagangan yang bersifat fashionable. 


\section{Keputusan Pembelian Konsumen \\ Konsep Keputusan Pembelian}

Kotler dan Armstrong (2008), mengemukakan bahwa keputusan pembelian adalah tahap proses keputusan dimana konsumen secara aktual melakukan pembelian produk. menentukan pesan dan mengalokasikan biaya anggaran.

\section{Pengembangan Hipotesis}

$\mathrm{H}_{\mathrm{a}} 1$ : Persepsi konsumen berpengaruh positif dan signifikan terhadap keputusan pembelian konsumen.

$\mathrm{H}_{\mathrm{a}} 2$ : Store atmosphere berpengaruh positif dan signifikan terhadap keputusan pembelian konsumen.

\section{Kerangka Konseptual}

Untuk dapat melihat pengaruh dari persepsi konsumen dan store atmosphere terhadap keputusan pembelian konsumen dan bagaimana masing-masing memberikan dampak terhadap keputusan pembelian konsumen, maka disusunlah bentuk penelitian dengan persepsi konsumen dan store atmosphere sebagai variabel independen dan keputusan pembelian sebagai variabel dependen dalam penelitian ini, sehingga dapat disusun kerangka pemikiran seperti di bawah ini :

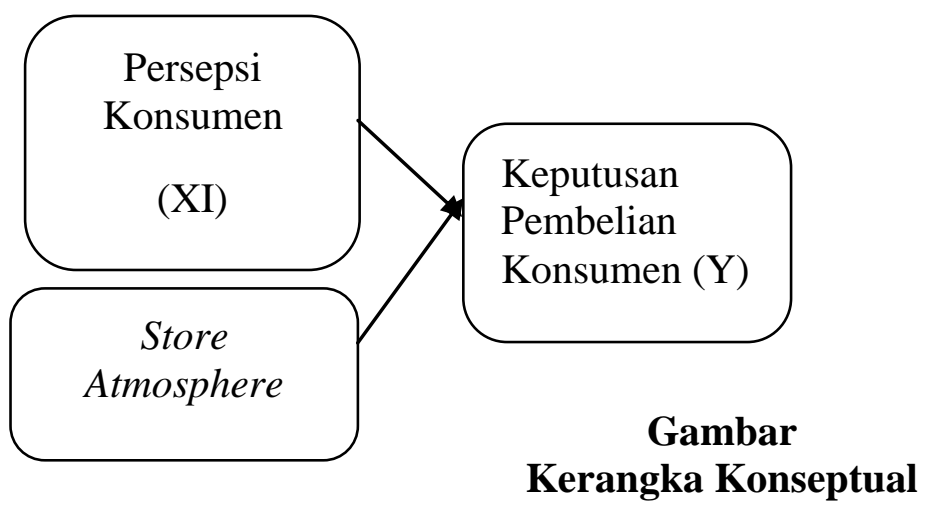

\section{METODE PENELITIAN}

\section{Jenis Penelitian}

Jenis penelitian ini adalah penelitian kuantitatif berupa pengumpulan dan pengukuran data yang berbentuk angka.

\section{Objek Penelitian}

Adapun yang menjadi objek pada penelitian ini adalah masyarakat kota Padang yang pernah berbelanja di Basko Grand Mall Padang

\section{Populasi}

Penelitian ini populasinya adalah pengunjung dari Basko Grand Mall Padang yang pernah berbelanja di Basko Grand Mall Padang.

\section{Sampel}

Metode pengambilan sampel yang digunakan adalah non probability sampling, dimana semua populasi tidak memiliki peluang yang sama untuk menjadi responden dan pengambilan sampel didasarkan pada pertimbangan peneliti (Sugiyono, 2012).

Oleh karena populasi tidak diketahui maka pengambilan sampel dilakukan dengan menggunakan rumus pendekatan Isac Michel (syofian, 2010). Dengan 
menggunakan tingkat kepercayaan 95\%, tingkat kesalahan $10 \%$, proporsi yang diharapkan dan proporsi yang tidak diharapkan masing-masing 0,5 .

Maka diketahui :

$$
\begin{array}{ll}
\alpha & =1-0,95=0,05 \\
\alpha / 2 & =0,05 / 2=0,025 \\
\mathrm{Z} & =1-0,025 \\
= & 0,975 \\
\mathrm{e} & \text { (dari distribusi normal 1,96) } \\
\mathrm{e} & 0,1 \\
\mathrm{n} & =\frac{(Z a / 2)^{2} p q}{e^{2}} \\
\mathrm{n} & =\frac{(1,96)^{2} \cdot 0,5 \cdot 0,5}{0,1^{2}} \\
\mathrm{n} & =96,04
\end{array}
$$

\section{Teknik Analisis Data}

\section{Uji Validitas}

1. Apabila $\mathrm{r}$ hitung $>\mathrm{r}$ tabel maka butir pernyataan dari masing-masing indikator adalah valid.

2. Apabila $\mathrm{r}$ hitung $<\mathrm{r}$ tabel maka butir pernyataan dari masing-masing indikator adalah tidak valid.

\section{Uji Reliabilitas}

Reliabilitas adalah ukuran yang menunjukkan konsistensi dari alat ukur dalam mengukur gejala yang sama di lain kesempatan (Sekaran, 2011). Pada program SPSS 16.0, metode ini dilakukan dengan metode Cronbach Alpha, dimana suatu kuesioner dikatakan reliabel jika nilai Cronbach Alpha lebih besar dari 0,60.

\section{Uji Asumsi Klasik}

\section{Uji Normalitas}

Untuk menentukan kenormalan data dapat diukur dengan melihat angka probabilitasnya atau nilai Asymptotic Significance, (1) jika probabilitas $>0,05$ maka distribusi dari populasi adalah normal, (2) jika probabilitas $<0,05$ maka populasi tidak terdistribusi secara normal.

\section{Uji Multikolinearitas}

Metode ini dilakukan dengan melihat nilai Variance Inflation Factor (VIF) dan Tolerance pada model regresi. Model regresi bebas dari multikolinearitas jika nilai VIF kecil dari 10 dan tolerance besar dari 0,1 (Ghozali, 2011).

\section{Uji Heteroskedastisitas}

Uji heteroskedastisitas bertujuan untuk menguji apakah model regresi terjadi ketidaksamaan varian dari residual satu pengamatan ke pengamatan lainnya. Model regresi yang baik adalah model yang tidak terjadi heteroskedastisitas.

\section{Analisis Regresi Linear Berganda}

Analisis regresi linear berganda digunakan untuk mengetahui pengaruh variabel bebas (persepsi konsumen dan store atmosphere) terhadap variabel terikat (keputusan pembelian konsumen). Untuk menguji variabel digunakan rumus:

$\mathrm{Y}=\mathrm{a}+\mathrm{b} 1 \mathrm{X} 1+\mathrm{b} 2 \mathrm{X} 2+\mathrm{e}$ 


\section{Uji Koefisien Determinasi (R2)}

Koefisien determinasi digunakan untuk mengetahui seberapa besar kemampuan variabel bebas menjelaskan variabel terikat. Nilai $R$ Square berkisar antara 0 sampai 1 . Nilai yang mendekati 1 berarti variabel bebas memberikan hampir semua informasi yang dibutuhkan untuk memprediksi variabel terikat (Ghozali, 2011).

\section{HASIL DAN PEMBAHASAN}

Karakteristik Responden Berdasarkan Jenis Kelamin

\section{Tabel 3}

Responden Berdasarkan Jenis Kelamin

\begin{tabular}{|c|c|c|}
\hline Jenis Kelamin & Jumlah & Persentase (\%) \\
\hline Laki - laki & 34 & $35,4 \%$ \\
\hline Perempuan & 62 & $64,6 \%$ \\
\hline Total & 96 & $100 \%$ \\
\hline
\end{tabular}

Berdasarkan tabel 3 dapat diketahui bahwa mayoritas responden adalah perempuan sebanyak 62 orang $(64.6 \%)$. Sedangkan sisanya adalah laki-laki sebanyak 34 orang $(35,4 \%)$.

\section{Karakteristik Responden Berdasarkan Usia}

\section{Tabel 4}

Responden Berdasarkan Usia

\begin{tabular}{|c|c|c|}
\hline Usia & Jumlah & Persentase (\%) \\
\hline $15-20$ Tahun & 15 & $15,6 \%$ \\
\hline $21-25$ Tahun & 35 & $36,5 \%$ \\
\hline $26-30$ Tahun & 25 & $26,0 \%$ \\
\hline$>30$ Tahun & 21 & $21,9 \%$ \\
\hline Total & 96 & $100 \%$ \\
\hline
\end{tabular}

Berdasarkan tabel 4 dapat diketahui bahwa responden paling banyak adalah yang berusia 21 - 25 tahun sebanyak 36,5\%. Sedangkan yang paling sedikit adalah berusia 15 - 20 tahun sebanyak $15,6 \%$.

Karakteristik Responden Berdasarkan Pekerjaan

Tabel 5

Responden Berdasarkan Jenis Pekerjaan

\begin{tabular}{|l|c|c|}
\hline \multicolumn{1}{|c|}{ Pekerjaan } & Jumlah & Persentase (\%) \\
\hline Pelajar / Mahasiswa & 30 & $31,2 \%$ \\
\hline Pegawai Negeri & 27 & $28,1 \%$ \\
\hline Swasta & 20 & $20,8 \%$ \\
\hline Lainnya & 19 & $19,8 \%$ \\
\hline Total & 96 & $100 \%$ \\
\hline
\end{tabular}

Berdasarkan tabel 5 dapat diketahui bahwa, konsumen yang paling banyak adalah mereka yang memiliki pekerjaan pelajar / mahasiswa sebanyak 31,2\% dan yang paling sedikit Lainnya seperti ibu rumah tangga sebanyak 19,8\%. 
Karakteristik Responden Berdasarkan Penghasilan

Tabel 6

Responden Berdasarkan Penghasilan

\begin{tabular}{|c|c|c|}
\hline Penghasilan & Jumlah & Persentase (\%) \\
\hline$<\operatorname{Rp} 500.000$ & 4 & $4,2 \%$ \\
\hline $\operatorname{Rp} 500.000-\operatorname{Rp} 1000.000$ & 30 & $31,2 \%$ \\
\hline $\mathrm{Rp} 1.000 .000-\mathrm{Rp} 3.000 .000$ & 41 & $42,7 \%$ \\
\hline$>\operatorname{Rp} 3.000 .000$ & 21 & $21,9 \%$ \\
\hline Total & 96 & $100 \%$ \\
\hline
\end{tabular}

Berdasarkan tabel 6 dapat diketahui bahwa, penghasilan konsumen yang paling banyak adalah mereka yang memiliki penghasilan Rp1.000.000 - Rp 3.000.000 sebanyak 42,7\% dan yang paling sedikit < Rp 500.000 sebanyak 4,2\%.

Karakteristik Responden Berdasarkan Pengeluaran

Tabel 7

Responden Berdasarkan Pengeluaran

\begin{tabular}{|c|c|c|}
\hline Penghasilan & Jumlah & Persentase (\%) \\
\hline$<\operatorname{Rp} 500.000$ & 4 & $4,2 \%$ \\
\hline Rp 500.000 - Rp 1000.000 & 36 & $37,5 \%$ \\
\hline $\operatorname{Rp} 1.000 .000-3.000 .000$ & 41 & $42,7 \%$ \\
\hline$>\operatorname{Rp} 3.000 .000$ & 15 & $15,6 \%$ \\
\hline Total & 96 & $100 \%$ \\
\hline
\end{tabular}

Berdasarkan tabel 7 dapat diketahui bahwa, pengeluaran konsumen yang paling banyak adalah mereka yang memiliki pengeluaran $\mathrm{Rp} 1.000 .000-\mathrm{Rp}$ 3.000.000 sebanyak $42,7 \%$ dan yang paling sedikit pengeluaran konsumen $<\mathrm{Rp}$ 500.000 sebanyak $4,2 \%$.

Karakteristik Responden Berdasarkan frekuensi Berbelanja di Basko Grand Mall

Tabel 8

Responden Berdasarkan frekuensi Berbelanja

\begin{tabular}{|c|l|l|}
\hline \multicolumn{1}{|c|}{ Frekuensi } & Jumlah & Persentase (\%) \\
\hline$<1 \mathrm{kali} /$ minggu & 18 & $18,8 \%$ \\
\hline $1-2 \mathrm{kali} /$ minggu & 30 & $31,2 \%$ \\
\hline $1-3 \mathrm{kali} /$ minggu & 26 & $27,1 \%$ \\
\hline$>3 \mathrm{kali} /$ minggu & 22 & $22,9 \%$ \\
\hline Total & 96 & $100 \%$ \\
\hline
\end{tabular}

Berdasarkan tabel 8 dapat diketahui bahwa, frekuensi berbelanja konsumen yang paling banyak adalah $1-2 \mathrm{kali} /$ minggu sebanyak $31,2 \%$ dan frekuensi berbelanja konsumen yang paling sedikit $<1$ kali /minggu 18,8\%. 
Uji Validitas

Tabel 9

Hasil Uji Validitas

\begin{tabular}{|c|c|c|c|c|}
\hline No & Pertanyaan & $\mathrm{r}$ tabel & r hitung & Keterangan \\
\hline \multicolumn{5}{|c|}{ Persepsi Konsumen (X1) } \\
\hline 1 & $\begin{array}{l}\text { Basko Grand Mall terletak di lokasi yang } \\
\text { strategis. }\end{array}$ & 0,169 & 0,521 & Valid \\
\hline 2 & $\begin{array}{l}\text { Aksesbilitas Basko Grand Mall mudah } \\
\text { dicapai dengan transportasi umum atau } \\
\text { pribadi. }\end{array}$ & 0,169 & 0,585 & Valid \\
\hline 3 & $\begin{array}{l}\text { Lingkungan disekitar Basko Grand Mall } \\
\text { merupakan daerah yang ramai. }\end{array}$ & 0,169 & 0,603 & Valid \\
\hline 4 & Keamanan Basko grand mall terjaga & 0,169 & 0,501 & Valid \\
\hline 5 & $\begin{array}{l}\text { Di Basko Grand Mall tersedia berbagai } \\
\text { macam produk yang dapat dibeli. }\end{array}$ & 0,169 & 0,596 & Valid \\
\hline 6 & $\begin{array}{l}\text { Produk yang ada di Basko Grand Mall } \\
\text { produk yang berkualitas. }\end{array}$ & 0,169 & 0,533 & Valid \\
\hline 7 & $\begin{array}{l}\text { Harga barang di Basko Grand Mall } \\
\text { terjangkau bagi konsumen. }\end{array}$ & 0,169 & 0,516 & Valid \\
\hline 8 & $\begin{array}{l}\text { Pelayanan yang ada di Basko Grand Mall } \\
\text { ramah dan sopan. }\end{array}$ & 0,169 & 0,549 & Valid \\
\hline 9. & $\begin{array}{l}\text { Adanya promosi yang dilakukan seperti } \\
\text { pemberian potongan harga. }\end{array}$ & 0,169 & 0,596 & Valid \\
\hline \multicolumn{5}{|c|}{ Store Atmosphere (X2) } \\
\hline 1 & $\begin{array}{l}\text { Storefront (tampak muka) Basko Grand mall } \\
\text { unik sehingga menarik pengunjung datang. }\end{array}$ & 0,169 & 0,652 & Valid \\
\hline 2 & $\begin{array}{l}\text { Heigtz and size of building (tinggi dan luas } \\
\text { bangunannya) memadai untuk menarik } \\
\text { konsumen datang. }\end{array}$ & 0,169 & 0,781 & Valid \\
\hline 3 & $\begin{array}{l}\text { Logo (Papan nama) Basko Grand Mall } \\
\text { terlihat jelas. }\end{array}$ & 0,169 & 0,758 & Valid \\
\hline 4 & $\begin{array}{l}\text { Akses entrance (pintu masuk) Basko Grand } \\
\text { Mall memiliki fungsi yang baik untuk } \\
\text { masuk keluarnya para pengunjung }\end{array}$ & 0,169 & 0,786 & Valid \\
\hline 5 & $\begin{array}{l}\text { Parkiran Basko Grand Mall cukup luas dan } \\
\text { dapat menampung kendaraan pengunjung. }\end{array}$ & 0,169 & 0,580 & Valid \\
\hline 6 & $\begin{array}{l}\text { Pencahayaan Basko Grand Mall baik dan } \\
\text { cukup terang }\end{array}$ & 0,169 & 0,698 & Valid \\
\hline 7 & $\begin{array}{l}\text { Temperatur di dalam Basko Grand mall } \\
\text { sejuk. }\end{array}$ & 0,169 & 0,415 & Valid \\
\hline 8 & $\begin{array}{l}\text { Adanya alunan Musik yang perdengarkan di } \\
\text { dalam Basko Grand Mall. }\end{array}$ & 0,169 & 0,607 & Valid \\
\hline 9 & Aroma Basko Grand mall terjaga. & 0,169 & 0,737 & Valid \\
\hline
\end{tabular}




\begin{tabular}{|c|c|c|c|c|}
\hline 10 & $\begin{array}{l}\text { Adanya pemakaian teknologi Di Basko } \\
\text { Grand Mall yang membuat pengunjung } \\
\text { merasa senang seperti penggunaan tangga } \\
\text { escalator. }\end{array}$ & 0,169 & 0,544 & Valid \\
\hline 11 & $\begin{array}{l}\text { Tersedianya Customers Space (Ruangan } \\
\text { Pelanggan) yang disediakan Basko Grand } \\
\text { Mall untuk meningkatkan kenyamanan } \\
\text { pengunjung seperti toilet. }\end{array}$ & 0,169 & 0,705 & Valid \\
\hline 12 & $\begin{array}{l}\text { Arus lalu lintas di dalam Basko Grand Mall } \\
\text { terarah. }\end{array}$ & 0,169 & 0,786 & Valid \\
\hline 13 & $\begin{array}{l}\text { Adanya pemberian tanda seperti informasi } \\
\text { harga di Basko Grand mall yang } \\
\text { memudahkan pengunjung mengetahui harga } \\
\text { produk. }\end{array}$ & 0,169 & 0,380 & Valid \\
\hline 14 & $\begin{array}{l}\text { Adanya ketertarikan pengunjung berbelanja } \\
\text { di Basko Grand Mall karena adanya papan } \\
\text { promosi yang di pajang. }\end{array}$ & 0,169 & 0,589 & Valid \\
\hline \multicolumn{5}{|c|}{ Keputusan Pembelian Konsumen (Y) } \\
\hline 1 & $\begin{array}{l}\text { Di Basko Grand mall terdapat berbagai } \\
\text { pilihan produk yang dapat di beli. }\end{array}$ & 0,169 & 0,703 & Valid \\
\hline 2 & $\begin{array}{l}\text { Di Basko Grand Mall terdapat berbagai } \\
\text { macam pilihan merek. }\end{array}$ & 0,169 & 0,633 & Valid \\
\hline 3 & $\begin{array}{l}\text { Di Basko Grand Mall produknya } \\
\text { berkualitas. }\end{array}$ & 0,169 & 0,574 & Valid \\
\hline 4 & $\begin{array}{l}\text { Peritel atau gerai-gerai yang terkabung } \\
\text { dalam Basko Grand Mall merupakan } \\
\text { produsen ternama seperti Department Store } \\
\text { Matahari, Kfc, dll. }\end{array}$ & 0,169 & 0,448 & Valid \\
\hline 5 & $\begin{array}{l}\text { Terdapat berbagai macam tempat yang dapat } \\
\text { di kunjungi di Basko Grand Mall seperti } \\
\text { tempat makan, tempat belanja pakaian, tas, } \\
\text { dll. }\end{array}$ & 0,169 & 0,454 & Valid \\
\hline 6 & $\begin{array}{l}\text { Mencari saat yang tepat untuk berbelanja } \\
\text { seperti saat diskon, akhir pekan, dll. }\end{array}$ & 0,169 & 0,647 & Valid \\
\hline 7 & $\begin{array}{l}\text { Metode pembayaran di Basko Grand Mall } \\
\text { sudah canggih dan ada bukti pembayaran } \\
\text { dari setiap pembelian yang di lakukan. }\end{array}$ & 0,169 & 0,621 & Valid \\
\hline
\end{tabular}

Dari tabel hasil rangkuman uji validitas persepsi konsumen, store atmosphere, dan keputusan pembelian konsumen untuk melihat valid atau tidaknya instrumen masing-masing variabel yaitu dengan membandingkan antara $r$ hitung dengan $r$ tabel. Jika $r$ hitung $<r$ tabel, maka butir pernyataan dinyatakan tidak valid dan sebaliknya jika $r$ hitung $>$ dari $r$ tabel, maka butir pernyataan dinyatakan valid (Sekaran, 2006). Perhitungan validitas melihat nilai corrected item-total correlation yang merupakan nilai $r$ hitung dari hasil perhitungan validitas instrumen penelitian. Nilai $r$ tabel dapat dilihat pada tabel $r$ statistik, 
dimana nilai $\mathrm{df}=\mathrm{N}-2$, karena kuesioner yang disebar sebanyak 96, maka $\mathrm{N}=$ 96. Jika mengikuti rumus $\mathrm{df}=96-2$, jadi yang dilihat adalah nilai df (94) $=$ 0,169. Maka instrumen masing-masing pertanyaan persepsi konsumen, store atmosphere, dan keputusan pembelian valid karena memiliki $\mathrm{r}$ hitung besar dari $\mathrm{r}$ tabel 0,169.

\section{Uji reabiliatas}

Tabel 10

Hasil Uji Reliabilitas

\begin{tabular}{|l|c|c|}
\hline \multicolumn{1}{|c|}{ Variabel } & $\begin{array}{c}\text { Cronbach's } \\
\text { Alpha }\end{array}$ & Keterangan \\
\hline Persepsi Konsumen & 0,842 & Reliabel \\
\hline Store Atmosphere & 0,920 & Reliabel \\
\hline Keputusan Pembelian Konsumen & 0,834 & Reliabel \\
\hline
\end{tabular}

Dari tabel 10 terlihat nilai cronbach alpha dari semua variabel lebih besar dari 0,60 maka dapat disimpulkan instrumen penelitian ini reliabel.

\section{Uji Asumsi Klasik}

Uji Normalitas

\section{Tabel 11}

One-Sample Kolmogorov-Smirnov Test

\begin{tabular}{|ll|r|}
\hline & & \multicolumn{2}{|c|}{ Unstandardized Residual } \\
\hline $\mathrm{N}$ & & 96 \\
Normal & Mean & .0000000 \\
Parameters & Std. Deviation & 1.83256694 \\
Most & Absolute & .081 \\
Extreme & Positive & .081 \\
Differences & Negative & -.056 \\
Kolmogorov-Smirnov Z & .798 \\
Asymp. Sig. (2-tailed) & .548 \\
\hline
\end{tabular}

a. Test distribution is Normal.

Berdasarkan uji normalitas dengan pendekatan Kolmogorov-Smirnov pada tabel $14 \mathrm{di}$ atas, dapat diketahui bahwa data terdistribusi normal. Hal ini dilihat melalui nilai Asymptotic Significance (2-tailed) sebesar 0,548. Karena signifikansi lebih dari 0,05 maka residual terdistribusi secara normal. 
Uji Multikolinearitas

Tabel 12

Coefficients $^{\mathbf{a}}$

\begin{tabular}{|ll|r|r|}
\hline \multirow{2}{*}{ Model } & \multicolumn{2}{|c|}{ Collinearity Statistics } \\
\cline { 3 - 4 } & & \multicolumn{1}{c|}{ Tolerance } & \multicolumn{1}{c|}{ VIF } \\
\hline 1 & X1 & .316 & 3.167 \\
& X2 & .316 & 3.167 \\
\hline
\end{tabular}

a. Dependent Variable: Y

Tabel 12 memperlihatkan nilai tolerance dan VIF dari semua variabel bebas. Nilai tolerance yang didapat adalah 0,316 dan nilai VIF adalah 3,167. Nilai tolerance dan VIF dari semua variabel bebas memenuhi kriteria dimana nilai tolerance besar dari 0,1 dan VIF kecil dari 10, maka dapat disimpulkan tidak terjadi multikolinearitas antar variabel bebas.

\section{Uji Heteroskedastisitas}

Uji heteroskedastisitas digunakan untuk melihat apakah dalam model regresi terjadi perbedaan varian dari residual pada satu pengamatan ke pengamatan yang lain. Uji heteroskedastisitas dilakukan dengan uji glejser,

Tabel 13

Coefficients $^{\mathbf{a}}$

\begin{tabular}{|c|c|c|c|c|c|}
\hline \multirow[b]{2}{*}{ Model } & \multicolumn{2}{|c|}{ Unstandardized Coefficients } & \multirow{2}{*}{$\begin{array}{c}\begin{array}{c}\text { Standardized } \\
\text { Coefficients }\end{array} \\
\text { Beta }\end{array}$} & \multirow[b]{2}{*}{$\mathrm{t}$} & \multirow[b]{2}{*}{ Sig. } \\
\hline & B & Std. Error & & & \\
\hline (Constant) & 3.410 & .756 & 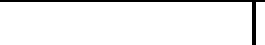 & 4.508 & .000 \\
\hline $\mathrm{X} 1$ & -.006 & .039 & -.028 & -.158 & .874 \\
\hline $\mathrm{X} 2$ & -.033 & .022 & -.263 & -1.491 & .139 \\
\hline
\end{tabular}

dimana signifikansi $>0,05$.

Berdasarkan tabel 13 dapat dilihat signifikansi variabel X1 dan X2 lebih besar dari 0,05. Dimana X1 (persepsi konsumen) 0,874>0,05 dan X2 (store atmosphere) 0,139>0,05. Jadi, dari hasil uji yang diperoleh tidak terjadi heteroskedastisitas. 
Analisis Regresi Linear Berganda

Uji Analisis Regresi Linear Berganda

Tabel 14

Hasil Uji Analisi Regresion Linear Berganda

\begin{tabular}{|c|c|c|c|c|c|}
\hline Model & $\begin{array}{r}\text { Unstand } \\
\text { Coeffi }\end{array}$ & $\begin{array}{l}\text { rdized } \\
\text { ients }\end{array}$ & $\begin{array}{c}\text { Standardized } \\
\text { Coefficients }\end{array}$ & & \\
\hline & B & Std. Error & Beta & $\mathbf{t}$ & sig \\
\hline $\begin{array}{l}1 . \\
\text { (Constant) }\end{array}$ & 2.611 & 1.290 & & 2.024 & .046 \\
\hline $\mathrm{X} 1$ & .311 & .067 & .376 & 4.653 & .000 \\
\hline $\mathrm{X} 2$ & .264 & .038 & .563 & 6.978 & .000 \\
\hline
\end{tabular}

persamaan regresi sebagai berikut :

$\mathrm{Y}=\mathrm{a}+\mathrm{b} 1 \mathrm{X} 1+\mathrm{b} 2 \mathrm{X} 2+\mathrm{e}$

$\mathrm{Y}=2,611+0,311 \mathrm{X} 1+0,264 \mathrm{X} 2$

Keterangan :

Y = keputusan pembelian konsumen

a $\quad=$ konstanta

$\mathrm{b} 1, \mathrm{~b} 2=$ koefisien regresi

$\mathrm{X} 1=$ persepsi konsumen

$\mathrm{X} 2 \quad=$ store atmosphere

Dari persamaan regresi diatas, dapat diinterprestasikan sebagai berikut :

1. a (konstanta) Artinya tanpa persepsi konsumen dan store atmosphere maka nilai keputusan pembelian konsumen sebesar 2,611. Dengan asumsi persepsi konsumen dan store atmosphere tidak mengalami perubahan.

2. b1(koefisien regresi persepsi konsumen) Artinya jika persepsi konsumen naik satu satuan dan variabel lain tetap maka keputusan pembelian akan naik sebesar 0,311 .

3. b2 (koefisien regresi store atmosphere) Artinya jika store atmosphere naik satu satuan dan variabel lain tetap maka keputusan pembelian akan naik sebesar 0,264.

Uji Koefisien Determinasi (R2)

Tabel 15

Hasil Uji Koefisien Determinasi

Model Summary ${ }^{b}$

\begin{tabular}{|l|r|r|rr|}
\hline Model & \multicolumn{1}{|c|}{$\mathrm{R}$} & R Square & \multicolumn{2}{|c|}{ Adjusted R Square } \\
\hline 1 & $.899^{\mathrm{a}}$ & .809 & .804 \\
\hline
\end{tabular}

Berdasarkan Tabel 15 terlihat tampilan output SPSS model summary besarnya Adjusted R square adalah 0,804 jadi peran atau kontribusi variabel independen (persepsi konsumen dan store atmosphere) sebesar 80,4\% terhadap variabel dependen (keputusan pembelian konsumen) sedangkan sisanya sebesar 19,6\% dipengaruhi oleh faktor lain yang tidak diteliti seperti faktor budaya, sosial, sikap, motivasi, gaya hidup dan lain-lain. 


\section{Uji Hipotesis}

Uji t

Tabel 16

Hasil Pengujian Uji t

Coefficients $^{\mathrm{a}}$

\begin{tabular}{|c|c|c|c|}
\hline Model & & & Sig. \\
\hline (Constant) & & 2.024 & .046 \\
\hline $\mathrm{X} 1$ & & 4.653 & .000 \\
\hline $\mathrm{X} 2$ & & 6.978 & .000 \\
\hline
\end{tabular}

Dari tabel 16 dapat dilihat nilai t hitung dan signifikasi dari masing-masing variabel bebas. Variabel persepsi konsumen dan variabel store atmosphere memiliki nilai $\mathrm{t}$ hitung $>\mathrm{t}$ tabel $1,661(\mathrm{df}=\mathrm{n}-1=96-1=95)$ dengan signifikansi $0,000<$ 0,05 maka persepsi konsumen dan store atmosphere secara parsial berpengaruh positif dan signifikan terhadap keputusan pembelian konsumen yang berarti $\mathrm{H}_{0} 1$ ditolak dan $\mathrm{H}_{\mathrm{a}} 1$ diterima.

\section{Uji F}

Table 17

ANOVA $^{\text {b }}$

\begin{tabular}{|ll|l|l|}
\hline \multicolumn{1}{|c|}{ Model } & \multicolumn{1}{|c|}{ F } & \multicolumn{1}{c|}{ Sig. } \\
\hline 1 & Regression & 196.416 & $.000^{\mathrm{a}}$ \\
& $\begin{array}{l}\text { Residual } \\
\text { Total }\end{array}$ & & \\
\hline
\end{tabular}

Dari tabel 17 di atas dapat dijelaskan dengan menggunakan taraf signifikansi 0,05 diperoleh $\mathrm{F}$ hitung 196,416 $>\mathrm{F}$ tabel 3,094 ( $\mathrm{dk}=\mathrm{n}-\mathrm{k}-1=96-2-1=93)$ dengan tingkat signifikansi yang diperoleh $0,000<0,05$ sehingga secara simultan persepsi konsumen dan store atmosphere berpengaruh positif terhadap keputusan pembelian konsumen pada Basko Grand Mall di kota Padang sehingga $\mathrm{H}_{0} 1, \mathrm{H}_{0} 2$ ditolak dan $\mathrm{H}_{\mathrm{a}} 1, \mathrm{H}_{\mathrm{a}} 2$ diterima.

\section{PENUTUP}

\section{Kesimpulan}

1. Dari hasil penelitian uji validitas dapat disimpulkan bahwa semua pertanyaan variabel persepsi konsumen (X1) dan store atmosphere (X2) valid karena nilai Corrected-total Correlatian $>0,169$.

2. Dari hasil penelitian berdasarkan uji reliabel diperoleh nilai Cronbach's Alpha untuk variabel persepsi konsumen (X1) dan store atmosphere (X2) dan keputusan pembelian konsumen (Y) lebih besar dari 0,60. Jadi, item-item pertanyaan untuk variabel penelitian dapat dipakai sebagai alat ukur dalam penelitian. 
3. Dari hasil penelitian uji regresi linear berganda dapat disimpulkan dilihat dari nilai a (konstanta) $=2,611$, artinya tanpa persepsi konsumen dan store atmosphere maka keputusan pembelian konsumen sebesar 2,611. b1 (koefisien regresi persepsi konsumen) $=0,311$ artinya ketika persepsi konsumen naik satu satuan dan variabel lain tetap maka keputusan pembelian akan naik sebesar 0,311 . b2 (koefisien regresi store atmosphere) $=0,264$ artinya ketika store atmosphere naik satu satuan dan variabel lain tetap maka keputusan pembelian akan naik sebesar 0,264.

4. Dari hasil uji koefisien determinasi diperoleh nilai Adjusted R squere sebesar 0,804 yang menunjukan bahwa variabel persepsi konsumen (X1) dan store atmosphere (X2) mempengaruhi keputusan pembelian konsumen 80,4\% dan sisanya dipengaruhi oleh faktor lain yang tidak diteliti oleh peneliti.

5. Dari hasil penelitian berdasarkan uji t dapat disimpulkan bahwa variabel persepsi konsumen dan variabel store atmosphere secara parsial mempunyai pengaruh positf dan signifikan terhadap keputusan pembelian konsumen di Basko Grand mall.

6. Dari hasil uji F dapat disimpulkan bahwa variabel persepsi konsumen dan store atmosphere secara simultan memiliki pengaruh positif dan signifikan terhadap keputusan pembelian konsumen di Basko Grand Mall.

\section{Saran}

1. Diharapkan pihak manajemen Basko Grand Mall dapat lebih memperhatikan harga dan kelengkapan produknya. Salah satu caranya bisa dilakukan dengan mengurangi biaya sewa toko-toko peritel yang terkabung didalam Basko Grand Mall yang ada didalamnya sehingga toko-toko peritel yang ada bisa mengurangi harga jual kepada konsumen. Di kelengkapan produknya pihak manajeman Basko Grand Mall dapat bekerja sama dengan pihak supliyer produk dari berbagai jenis sehingga kelengkapan produk dapat terlengkapi. Dengan begitu akan menimbulkan persepsi konsumen yang positif.

2. Diharapkan pihak manajemen Basko Grand Mall juga memperhatikan general interiornya yang berhubungan dengan pencahayaan dan temperature. Pihak Basko Grand Mall harus menambah tingkat penerangan dan suhu di dalam Basko Grand mall sehingga konsumen merasa senang berbelanja.

3. Diharapkan pada peneliti selanjutnya dapat menambahkan variabel lain yang mungkin mempengaruhi keputusan pembelian konsumen selain variabel bebas persepsi konsumen dan store atmosphere yang diteliti dalam penelitian ini. Bagi pihak lain, hasil penelitian ini dapat dijadikan bahan referensi pengetahuan bagi penelitian mendatang pada kasus yang sama.

\section{DAFTAR PUSTAKA}

Andika, A., \& Susanti, F. (2018). Pengaruh Marketing Mix Terhadap Keputusan Pembelian Parfum di Azzwars Parfum Lubeg Padang. https://doi.org/10.31227/osf.io/upgc3 
Aziz, N. (2019). Analisis Pengaruh Kualitas Produk, Harga, Promosi Terhadap Keputusan Pembelian Air Minum Dalam Kemasan (AMDK) Merek Aicos Produksi Pt. Bumi Sarimas Indonesia. https://doi.org/10.17605/OSF.IO/8XKYB

Berman, Evans. 2001. Retail Managemet : A Strategic Approach. New Jersey: Prentice Hall.

Cooper, D. R. Pamela, S. Schindler. 2006. Bussiness Research Method. Edisi 9. Mcgraw Hill International Edition.

Dessyana, Cindy Juwita. 2013. Store Atmosphere Pengaruhnya terhadap Keputusan Pembelian di Texas Chicken Multimart II Manado. Jurnal EMBA, Vol.1 No. 3 Juni 2013, Hal. 844-852.

Fandy, Tjiptono. 2005. Prinsip-prinsip Total Quality Service, Andi Offset. Yogyakarta.

Ferdinand, Augusty Tae. 2006. Structural Equation Modelling dalam Penelitian Manajemen. Edisi 4. Semarang: Badan Penerbit Universitas Diponegoro.

Fernandes, Y. D., \& Marlius, D. (2018). Peranan Customer Service Dalam Meningkatkan Pelayanan Kepada Nasabah Pada PT. Bank Pembangunan Daerah Sumatera Barat Cabang Utama Padang. https://doi.org/10.31227/osf.io/wrh3p

Jamarnis, S., \& Susanti, F. (2019). Pengaruh Harga Dan Periklanan Melalui Internet Terhadap Keputusan Pembelian Produk Sabun Merek Lux Pada Mahasiswa STIE “KBP” Padang. https://doi.org/10.31227/osf.io/xz3d8

Kotler, Philip, dan Kevin Lane Keller. 2012. Marketing Management. 14th ed. Pearson Education, Inc. New Jersey.

Kurniawan, R., \& Susanti, F. (2019). Pengaruh Lifestyle Terhadap Keputusan Pembelian Pada Sepatu Merek Fladeo Di Basko Grand Mall Padang. https://doi.org/10.31227/osf.io/ehyau

Lovelock, Christopher H, dan Lauren K Wrigh .2005. Mnajemen Pemasaran Jasa. Jakarta: PT Indeks.

Marlius, D. (2017). Keputusan Pembelian Berdasarkan Faktor Psikologis Dan Bauran Pemasaran Pada PT. Intercom Mobilindo Padang. Jurnal Pundi. Volume 1. No. 1. Hal. 57-66. https://doi.org/10.31575/jp.v1i1.9

Mayliza, R. (2019). Pengaruh Kesadaran Merek, Asosiasi Merek Dan Perception Of Quality Terhadap Keputusan Pembelian Hospital Bed Merek Paramout 
Di PT. Aga Medika Utama Padang (Studi Kasus Rumah Sakit Umum Kota Padang). https://doi.org/10.17605/OSF.IO/VYQ4E

Mowen, J C. dan Michael Minor. 2002. Perilaku Konsumen. Edisi Kelima, Jilid I. Jakarta: Erlangga.

Mantik, Ardy F, Lisbeth Mananeke, dan Hendra Tawas. 2015.

Susanti, F. (2015). Pengaruh Bauran Promosi Terhadap Keputusan Klien Dalam Memilih Radio Carano Sebagai Media Promosi Iklan. https://doi.org/10.31227/osf.io/b9ws7 